\title{
Cloning and Expression of the $\mathbf{A}_{2 \mathrm{a}}$ Adenosine Receptor from Guinea Pig Brain*
}

\author{
Fan Meng, ${ }^{1}$ Guo-xi Xie, ${ }^{1}$ Derek Chalmers, ${ }^{1}$ Caurnel Morgan, ${ }^{1}$ Stanley J. Watson, Jr., ${ }^{1}$ \\ and Huda Akil ${ }^{1}$
}

(Accepted: December 7, 1993

\begin{abstract}
A full-length complementary DNA (cDNA) clone encoding the guinea pig brain $\mathrm{A}_{2}$ adenosine receptor has been isolated by polymerase chain reaction (PCR) and low-stringency-hybridization screening of a guinea pig brain cDNA library. This cDNA contains a long open reading frame encoding a 409 -amino acid-residue protein which is highly homologous to the $\mathrm{A}_{2}$ adenosine receptors previously cloned from other species. Hydrophobicity analysis of the deduced protein sequence reveals seven hydrophobic regions, characteristic of a member of the G-protein-coupled receptor superfamily. Radioligand binding assay and functional (GTPase and cAMP) assays of the receptor, transiently expressed in mammalian cells, demonstrate typical characteristics of the $A_{2}$ type adenosine receptor. The messenger RNA (mRNA) of this $A_{2}$ receptor is found in the brain, heart, kidney and spleen. Receptor autoradiography with $\left[{ }^{3} \mathrm{H}\right] \mathrm{CGS} 21680$, a specific $\mathrm{A}_{2}$ agonist, and in situ hybridization with $A_{2}$ cRNA probe in guinea pig brain indicate that the receptor is expressed exclusively in the caudate nucleus. The pharmacological profile and anatomical distribution of this receptor indicate that it is of the $\mathrm{A}_{2 \mathrm{a}}$ subtype. This work represents the first cloning of an $A_{2 \mathrm{a}}$ receptor in a rodent species, offers a complete pharmacological characterization of the receptor and provides an anatomical comparison between binding profile and gene expression of the receptor.
\end{abstract}

KEY WORDS: Gs-coupled receptor; adenylyl cyclase; radioligand binding; mammalian cell expression; in situ hybridization; caudate/putamen.

\section{INTRODUCTION}

Adenosine, a member of the purinergic neurotransmitter system, mediates a variety of important physiological functions, such as sedation, pain modulation, presynaptic inhibition of neurotransmitter release, inhibition of cardiovascular activity, regulation of renal glomerular filtration, and regulation of immune system, white blood cell and platelet functions $(24,40)$. Adenosine initiates

\footnotetext{
${ }^{1}$ Mental Health Research Institute, The University of Michigan, Ann Arbor, Michigan 48109.

* Special issue dedicated to Dr. Bernard W. Agranoff
}

\begin{abstract}
Abbreviations: $\mathrm{ADAC}$, adenosine amine congener; $\mathrm{BA}, \mathrm{N}^{6}$-benzyladenosine; bp, nucleotide base pair; cAMP, cyclic adenosine $3^{\prime}, 5^{\prime}$ monophosphate; CCPA, 2-chloro-N $N^{6}$-cyclopentyladenosine; CGS 21680, 2-p-(2-carboxyethyl)phenethylamino- $5^{\prime} \cdot \mathrm{N}$-ethylcarboxamido adenosine hydrochloride; CHA, $\mathrm{N}^{6}$-cyclohexyladenosine; CNS, central nervous system; CPA, $\mathrm{N}^{6}$-cyclopentyladenosine; $\mathrm{CPX}$, 8-cyclopentyl-1,3dipropylxanthine; DME, Dulbecco's modified Eagle's medium; DMPX, 3,7-dimethyl-1-propargylxanthine; DPMX, 1,3-dipropyl-7-methylxanthine; DPX, 1,3-dipropyl-8-(2-amono-4-chlorophenyl)xanthine; FCS, fetal calf serum; IBMX, 3-isobutyl-1-methylxanthine; KHB, KrebHEPES buffer; MECA, 5'-N-methylcarboxamidoadenosine; NECA, $5^{\prime}$-N-ethylcarboxamidoadenosine; D-PBS, Dulbecco's phosphate buffered saline; PCR, polymerase chain reaction; R-PIA, R(-)-N $\mathrm{N}^{6}-(2-$ phenylisopropyl)adenosine; SSPE, sodium chloride-sodium phosphate-EDTA buffer; TM, transmembrane domain; XAC, xanthine amine congener.
\end{abstract}


these actions by binding to its specific receptors in the membranes of target cells. Adenosine receptors are pharmacologically classified into two main types, $A_{1}$ and $A_{2}$. The $\mathrm{A}_{1}$ type adenosine receptor inhibits adenylyl cyclase and therefore decreases cAMP levels, while $\mathrm{A}_{2}$ stimulates adenylyl cyclase (35). Species differences in highaffinity $A_{1}$ and $A_{2}$ binding have been reported based on the binding studies with mammalian brain membranes $(6,36) . A_{1}(16,17,19,26,38)$ and $A_{2}(16,18,25,34)$ adenosine receptors have been cloned from several species. This has established a new subfamily within the superfamily of the G-protein-coupled receptors; new adenosine receptor subtypes (42), which had not been discerned by binding studies, have emerged from molecular cloning including the $A_{2 a}$ and $A_{2 b}$ subtypes. However, the $A_{2 a}$ subtype has only been cloned from dog and human, making it difficult to characterize its anatomy and pharmacology in smaller experimental animals. Here we report the cloning of a cDNA, named $g \mathrm{pA}_{2} \mathrm{R}$, encoding the $A_{2 \mathrm{a}}$ adenosine receptor from guinea pig brain; we describe the pharmacological characterization of this receptor in transiently transfected cells, and its expression in guinea pig brain and other tissues.

\section{EXPERIMENTAL PROCEDURE}

Poly (A) RNA preparation and cDNA library construction. Total RNA was isolated from male Hartley guinea pig brains by guanidinium thiocyanate extraction followed by centrifugation in cesium chloride solution (28). Poly(A)+ RNA was purified using an oligo-dT cellulose spun column (Pharmacia). The construction of cDNA library was principally based on the method developed by Okayama and Berg (23) and modified by Gubler and Hoffman (12). The first-strand cDNA was synthesized by AMV reverse transcriptase using oligo(dT)-Not I PrimerAdaptor [oligo(dT) $)_{15}$ containing Not I site on its $5^{\prime}$ side, Promega]; the second strand $\mathrm{cDNA}$ was synthesized using E.coli DNA polymerase I and RNase $\mathrm{H}$. After treatment with $\mathrm{T}_{4}$ DNA polymerase to blunt their ends, the double-stranded CDNAs were ligated with Bst XI linker (Invitrogen) by $\mathrm{T}_{4}$ ligase at $14^{\circ} \mathrm{C}$ for $24 \mathrm{~h}$. The cDNAs were digested by restriction enzyme Not I to create Not I sticky ends, then loaded on $1 \%$ agarose gel and electrophoresed for size fractionation. The cDNAs with sizes $>1.5 \mathrm{~kb}$ were electroeluted from the gel to DE81 ion exchange paper (Whatman) and recovered by eluting with $1 \mathrm{M}$ $\mathrm{NaCl}$. After ethanol precipitation and washing, the cDNAs were unidirectionally inserted into the Bst XI-Not I sites of pME18S expression vector by $\mathrm{T}_{4}$ ligase to construct the cDNA library. This size-fractionated $(>1.5 \mathrm{~kb})$ guinea pig brain cDNA library was composed of 1.8 $\times 10^{6}$ independent colonies transformed into host $\mathrm{DH}_{5 \alpha}$ competent cells.

The pME18S vector(20), containing the Hae II-Aat-II fragment from pUC18, the stuffer region from plasmid CDM8 and the $\mathrm{SR}_{\alpha}$ promoter (37), with stop codon in each frame immediately after the cDNA insert, is a high-copy numbered ( $\sim 5-10 \mathrm{mg}$ plasmid/L culture), small vector $(3.4 \mathrm{~kb})$ plasmid with a strong promoter, suitable for constructing size-sclected, unidirectional cDNA libraries and for expression in different mammalian cell systems.
Oligonucleotide Primer Design and PCR Amplification. Six oligonucleotides were synthesized based on published G-protein-coupled receptor cDNA sequences.

Three forward:

(1) 5'-AAC(T)C(T)A(T)ITTC(T)A(C)TIATIA(T) CIC-

TIGCITC(G)IGCI GA-3';

(2) $5^{\prime}$-A(C)GITTIC(T)TIATGTGC(T)AAC(T)CTIA

(T)C(G)C(T)TTC(T) GCIGA-3';

(3) 5'-ACIGTITAC(T)ATIACICAC(T)C(T)TIA(T)C(G) IATIGCIGA-3'.

Three reversed:

(4) $5^{\prime}$-GCC(T)TTIGTA(G)AAIATIGCA(G)TAIAGA(G)

AAIGGA(G)TT-3';

(5) 5'-AAA(G)TCIGGA(G)C(G)A(T)ICGIC(G)AA

(G)TAIATC(G)AIIGGA (G)TT-3';

(6) $5^{\prime}-\mathrm{C}(\mathrm{G}) \mathrm{A}(\mathrm{T}) \mathrm{IC}(\mathrm{G}) \mathrm{A}(\mathrm{T}) \operatorname{ICCIACA}(\mathrm{G}) \mathrm{AAA}$

(G)TAIATA(G)AAIGGA(G) TT-3'.

Every possible combination of one forward and one reversed oligonucleotides was employed as one set of primers for polymerase chain reaction (PCR) (27).

Taq polymerase and all other PCR reagents were purchased from Perkin Elmer. Guinea pig brain cDNAs were used as PCR templates, Five fmol of DNA templates, $1 \mu \mathrm{M}$ of each primer, $200 \mu \mathrm{M}$ of each $\mathrm{dNTP}$ and 5 units of Taq Polymerase were used in each $100 \mu$ l-volume reaction. The PCR temperature cycle on the DNA Tempcycler (Coy Laboratory) was set as follows: for the first five cycles, denaturation at $94^{\circ} \mathrm{C}$ for $1 \mathrm{~min}$, annealing at $37^{\circ} \mathrm{C}$ for $2 \mathrm{~min}$, extension at $50^{\circ} \mathrm{C}$ for $5 \mathrm{~min}$; for the next 30 cycles, denaturation at $94^{\circ} \mathrm{C}$ for $1 \mathrm{~min}$, annealing at $50^{\circ} \mathrm{C}$ for $2 \mathrm{~min}$ and extension at $72^{\circ} \mathrm{C}$ for $3 \mathrm{~min}$; the last five cycles have an extension time of $10 \mathrm{~min}$ at $72^{\circ} \mathrm{C}$ in each cycle.

Aliquots of the PCR products were directly loaded on $1.2 \%$ agarose gel to analyze their sizes. DNAs from bands of $0.4-1.2 \mathrm{~Kb}$ were recovered by electroelution, ligated into Eco RV site of pBluescript KS II (Stratagene) for sequencing analysis and for preparing ${ }^{32} \mathrm{P}$-labeled probes for the colony hybridization.

Colony Hybridization and DNA Sequencing. About $3 \times 10^{5}$ E.coli colonies from the guinea pig brain cDNA library were lifted onto Nytran filters (S\&S). PCR product probe was labeled with ${ }^{32} \mathrm{P}$ by the random primer method (5). The conditions for low stringency hybridization were: $35 \%$ formamide, $5 \times$ SSPE, $5 \times$ Denhardt's solution, $0.5 \%$ SDS, $100 \mu \mathrm{g} / \mathrm{ml}$ denatured salmon sperm DNA (Pharmacia), 1 $\times 10^{\circ} \mathrm{cpm}$ probe $/ \mathrm{ml}, 42^{\circ} \mathrm{C}, 24 \mathrm{~h}$. Washing was conducted at $37^{\circ} \mathrm{C}$ three times with $2 \times$ SSPE, $0.2 \%$ SDS for $30 \mathrm{~min}$ each. Positive colonies were picked and further purified to single clones by second round screening and southern hybridization with ${ }^{32} \mathrm{P}$-probes.

Both strands of cloned cDNA were sequenced by dideoxynucleotide chain termination method (30) with Sequenase (USB). DNA and deduced protein sequences were analyzed by GCG programs (Wisconcin).

Mammalian Cell Transfection and Receptor Binding Assay. Simian COS-7 cells were transfected with CsCl-gradient-centrifugationpurified plasmids by electroporation (22). Exponentially growing COS7 cells were plated $\left(5 \times 10^{5}\right.$ cells $/ 10 \mathrm{~cm}$ dish $)$ in DME medium with $10 \% \mathrm{FCS}$ and cultured in a $37^{\circ} \mathrm{C}, 5 \% \mathrm{CO}_{2}$ incubator. After $24 \mathrm{~h}$, cclls were harvested and washed twice with D-PBS, then resuspended in 1 $\mathrm{ml}$ D-PBS containing $10 \mu \mathrm{g}$ of plasmid DNA in a sterile electroporation cuvette. After sitting on ice for $5 \mathrm{~min}$, the cells were electroporated $\left(330 \mu F, 300 \mathrm{~V}, 4^{\circ} \mathrm{C}\right)$ in a Cell-Porator (BRL), then sat on ice for $5 \mathrm{~min}$, followed by suspension in $10 \mathrm{ml}$ DMEM containing $10 \% \mathrm{FCS}$ in a cell culture dish and incubated at $37^{\circ} \mathrm{C}, 5 \% \mathrm{CO}_{2}$

After three days of culturing, transfected cells were harvested by treatment with D-PBS (without calcium and magnesium) containing 
D.5 mM EDTA, 0.01\% sodium azide, washed three times with $\mathrm{KHB}$ $115 \mathrm{mM} \mathrm{NaCl}, 4.8 \mathrm{mM} \mathrm{KCl}, 2.5 \mathrm{mM} \mathrm{CaCl}, 5 \mathrm{mM} \mathrm{MgCl} 25 \mathrm{mM}$ HEPES, $\mathrm{pH}$ adjusted to 7.4 with $\mathrm{NaOH}$ ) and resuspended in $1 \times 10^{6}$ cells/ml in KHB. Receptor binding assays were performed in $1 \mathrm{ml}$ KHB with $1 \times 10^{5}$ cells, competitors and radiolabeled ligands. In order to label different types of adenosine receptors, tritiated $A_{1}$ agonists 2-chloro- $\mathrm{N}^{6}$-[cyclopentyl-2,3,4,5- ${ }^{3} \mathrm{H}$-Cyclopentyladenosine ([ $\left.{ }^{3} \mathrm{H}\right] \mathrm{CCPA}$, specific activity: $\left.35.4 \mathrm{Ci} / \mathrm{mmole}, \mathrm{NEN}\right)$ and Cyclohexyladenosine $\left(\left[{ }^{3} \mathrm{H}\right] \mathrm{CHA}, 30.2 \mathrm{Ci} /\right.$ mmole, $\left.N E N\right)$, tritiated $A_{1}$ antagonist 8-[dipropyl-2,8- $\left.{ }^{3} \mathrm{H}(\mathrm{N})\right]$ Cyclopentyl-1,3-dipropylxant hine $\left(\left[{ }^{3} \mathrm{H}\right] \mathrm{CPX}\right.$, $108.0 \mathrm{Ci} / \mathrm{mmole} \mathrm{NEN})$, and tritiated $\mathrm{A}_{2}$ agonist [carboxyethyl. ${ }^{3} \mathrm{H}(\mathrm{N})$ ]CGS 21680 (39.6 Ci/mmole, NEN) were used. Unlabeled ligands (all from Research Biochemicals Incorporated, MA) used for competition were: the $A_{1}$ selective agonists CCPA, CPA and CHA, relatively $A_{1}$ selective agonists $A D A C, R-P I A$ and $B A_{2}$ the $A_{1}$ selective antagonists $\mathrm{CPX}$ and DPX, the relatively $\mathrm{A}_{1}$ selective antagonists $X A C$ and IBMX, the selective $A_{2}$ agonist $C G S 21680 \mathrm{HCl}$, the relatively $A_{2}$ selective agonist MECA, the relatively selective $A_{2}$ antagonists DMPX and DPMX, and the non-selective agonist NECA, as well as adenosine and ATP. For saturation studies, various concentrations of radiolabeled ligands were used, nonspecific binding was determined in the presence of $20 \mu \mathrm{M}$ unlabeled R-PIA for $\mathrm{A}_{1}$ and $20 \mu \mathrm{M}$ unlabeled CGS 21680 $\mathrm{HCl}$ for $\mathrm{A}_{2}$; in a parallel experiment, 5 units/ml of adenosine deaminase was included in the binding assay buffer to determine the influence of endogenously released adenosine in this binding system. For competition studies, minimum amounts of radiolabeled ligands were used to give about $3000 \mathrm{cpm}$ specific binding per tube, and various concentrations of unlabeled ligands were used as competitors. The assay reaction mixtures were incubated at room temperature for $1.5 \mathrm{~h}$ and stopped by sitting on ice for $5 \mathrm{~min}$. Cells bound with radioligands and free ligands were separated by filtering through glass fiber filters (\#32, S \& S) on a multi-channel cell harvester (M-24S, Brandel). The filter membranes were counted for radioactivity in scintillation solution. Binding assay data were presented as the mean value of three experiments, and analyzed by the Ligand program (21).

GTPase Assay. GTPase assays (2) were performed with transiently transfected COS-7 cells. Briefly, plasmid pME18S-gp $A_{2} R$ transfected $\mathrm{COS}$ cell membranes were prepared by homogenization and centrifugation in $10 \mathrm{mM}$ Tris-HCl buffer containing $0.1 \mathrm{mM}$ EDTA, $\mathrm{pH}$ 7.5. Ten mg of membrane protein in a $10 \mu \mathrm{l}$ volume was added to $85 \mu 1$ reaction mixture containing $0.5 \mu \mathrm{M}\left[\gamma_{-}{ }^{32} \mathrm{P}\right] \mathrm{GTP}, 1 \mathrm{mM}$ AppNHp, $1 \mathrm{mM}$ ATP, $1 \mathrm{mM}$ Ouabain, $10 \mathrm{mM}$ creatine phosphate, 5 units of creatine phosphokinase, $2 \mathrm{mM}$ dithiothteitol, $5 \mathrm{mM} \mathrm{MgCl}$, $100 \mathrm{mM} \mathrm{NaCl}, 0.1 \mathrm{mM}$ EDTA, $12.5 \mathrm{mM}$ Tris-HCl, pH 7.5, then placed on ice before the addition of adenosine receptor agonists. Immediately after the addition of $\mathrm{A}_{1}$ agonist $\mathrm{CPA}$ (final concentration: $10 \mu \mathrm{M}$ and $1 \mu \mathrm{M}$ ) or $\mathrm{A}_{2}$ agonist CGS 21680 (final concentration: 10 $\mu \mathrm{M}$ and $1 \mu \mathrm{M}$ ), the reaction tubes were transferred to $37^{\circ} \mathrm{C}$ for 20 min. The reaction was terminated on ice with the addition of $0.9 \mathrm{ml}$ of stop solution containing $20 \mathrm{mM}$ phosphoric acid and $5 \%$ activated charcoal, $\mathrm{pH}$ 2.3. After centrifugation in an Eppendorf microcentrifuge at $4^{\circ} \mathrm{C}$ for $10 \mathrm{~min}$, the radioactivity was measured from the supernatants.

Cyclic AMP Assay. COS-7 cells transfected with plasmid pME18Sgp $\mathrm{A}_{2} \mathrm{R}$ were cultured in DMEM, $10 \% \mathrm{FCS}$ for two days, washed twice with IMDM, and then cultured in IMDM, $10 \%$ Hyclone FCS. Different concentration of the $A_{1}$ agonist CPA, the $A_{2}$ agonist CGS 21680 , or the A2 antagonist DMPX were added to the cell culture and incubated at $37^{\circ} \mathrm{C}$ for $30 \mathrm{~min}$. To terminate the reaction, $30 \%$ trichloroacetic acid (ice cold, equal volume to the cell culture media) was added to the dish. The cells were scraped into a glass test tube and put on ice for $30 \mathrm{~min}$ for a complete precipitation. After centrifugation at
$2000 \mathrm{~g}$ at $4^{\circ} \mathrm{C}$ for $10 \mathrm{~min}$, the supernatant was ether extracted, lyophilized on a Speed Vac and resuspended in $50 \mathrm{mM}$ Tris- $\mathrm{HCl}, 2 \mathrm{mM}$ EDTA, pH 7.5. Cyclic AMP levels were measured with a cAMP Assay Kit (TRK 432, Amersham).

Northern Blot Analysis. All the Northern and in situ hybridizations were conducted with ${ }^{32} \mathrm{P}$ or ${ }^{35} \mathrm{~S}$-labeled $\mathrm{CRNA}$ riboprobes. $\mathrm{A}_{2}$ CRNA riboprobe was produced from a $900 \mathrm{bp}$ Pst I fragment of the $\mathrm{gpA}_{2} \mathrm{R}$ cDNA ligated into pBluescript $\mathrm{KS} \mathrm{II}(-)$ (Stratagene). [ $\left.{ }^{32} \mathrm{P}\right] \mathrm{UTP}$ or $\left[{ }^{35}\right.$ S $]$ UTP-labeled Riboprobes were produced using either T3 or T7 transcription systems in a standard labeling reaction mixture. The reaction was incubated at $37^{\circ} \mathrm{C}$ for 90 minutes, labelled probe being separated from free nucleotides over a Sephadex G-50 column.

Total RNA was extracted from brain and peripheral tissues of a male Hartley guinea pig using GITC and $\mathrm{LiCl}$. The RNA samples were fractionated on a $1 \%$ agarose-formaldehyde gel, electrophoresed and then transferred onto a nylon filter (Nytran). The filter was hybridized with $5 \times 10^{5} \mathrm{cpm} / \mathrm{ml}$ 32P-labeled RNA probe from $\mathrm{gpA}_{2} \mathrm{R}$ under high stringency conditions (50\% Formamide, $5 \mathrm{X} \mathrm{SSPE}, 5 \mathrm{X}$ Denhardt's reagent, $0.5 \% \mathrm{SDS}, 70^{\circ} \mathrm{C}, 24 \mathrm{~h}$ ). The filter was washed once with $1 \mathrm{X} \mathrm{SSPE}, 0.5 \%$ SDS at $70^{\circ} \mathrm{C}$ for $30 \mathrm{~min}$ and twice with $0.1 \mathrm{X} \mathrm{SSPE}, 0.5 \%$ SDS at $70^{\circ} \mathrm{C}$ for $30 \mathrm{~min}$. and then exposed to an $x$-ray film (Kodak) with two intensifying screens for 7 days at $-80^{\circ} \mathrm{C}$.

In Situ Hybridization. Guinea pig brain sections were removed from storage at $-80^{\circ} \mathrm{C}$ and placed dircctly into $4 \%$ buffered paraformaldehyde at room temperature. After 60 minutes, slides were rinsed in isotonic phosphate buffered saline (10 minutes) and treated with protcinase $\mathrm{K}(1 \mu \mathrm{g} / \mathrm{ml}$ in $100 \mathrm{mM}$ Tris/HCL, pH8.0) for 10 minutes at $37^{\circ} \mathrm{C}$. Subsequently, sections underwent successive washes in water (1 minute), $0.1 \mathrm{M}$ triethanolamine ( $\mathrm{pH} 8.0$, plus $0.25 \%$ acetic anhydride) for 10 minutes and $2 X \mathrm{SSC}(0.3 \mathrm{mM} \mathrm{NaCl}, 0.03 \mathrm{mM}$ sodium citrate, $\mathrm{pH} 7.2$ ) for 5 minutes. Sections were then dehydrated through graded alcohols and air dried.

Post-fixed sections were hybridized with $1.0 \times 10^{6} \mathrm{dpm}\left[{ }^{35}\right.$ S]UTPlabeled riboprobes in bybridization buffer containing $75 \%$ formamide, $10 \%$ dextran sulphate, $3 \mathrm{X} \mathrm{SSC}, 50 \mathrm{mM}$ sodium phosphate buffer (pH7.4), 1 X Denhardts solution, $0.1 \mathrm{mg} / \mathrm{ml}$ yeast $\mathrm{tRNA}$ and $10 \mathrm{mM}$ dithiothreitol in a total volume of $25 \mathrm{ml}$. The diluted probe was applied to sections on a glass coverslip which was sealed into place with rubber cement. Sections were hybridized overnight at $55^{\circ} \mathrm{C}$ in a humid environment. $A_{2}$ probe specificity was confirmed by absence of signal in both sections labeled with sense $A_{2}$ probe and sections pre-treated with RNase prior to hybridization with antisense (cRNA) $A_{2}$ probc.

Post-hybridization the rubber cement was removed and sections were washed in $2 X$ SSC for 5 minutes and then treated with RNase A $(200 \mu \mathrm{g} / \mathrm{ml}$ in $10 \mathrm{mM}$ Tris $/ \mathrm{HCL}$, pH8.0, containing $0.5 \mathrm{M} \mathrm{NaCl})$ for 60 minutcs at $37^{\circ} \mathrm{C}$. Subsequently, sections were washed in $2 X$ SSC for 5 minutes, $1 \times$ SSC for 5 minutes, $0.5 \times$ SSC for 60 minutes at hybridization temperature, $0.5 \times \mathrm{SSC}$ at room temperature for $5 \mathrm{~min}$ utes and then dehydrated in graded alcohols and air dricd. For signal detection, sections were placed on Kodak XAR-5 X-ray film and eXposed for 2 days at room temperature.

In Vitro Receptor Autoradiography. $\left[{ }^{3} \mathrm{H}\right] \mathrm{CGS} 21860$ binding was performed according to previously published autoradiographic methods (4). Slide-mounted tissue sections were preincubated in $0.17 \mathrm{M} \mathrm{Tris/}$ $\mathrm{HCl}, \mathrm{pH} 7.4$, for 20 minutes at room temperature. Subsequently, sections were incubated with $10 \mathrm{nM}\left[{ }^{3} \mathrm{H}\right] \mathrm{CGS} 21860(+0.5 \mathrm{i} . \mathrm{u} . / \mathrm{ml}$ adenosine deaminase) for 90 minutes at room temperature. Post-incubation, slides were washed in incubation buffer $(2 \times 5$ minutes $)$ and dried in a stream of cold air. Non-specific binding was determined in the presence of $10 \mu \mathrm{M}$ adenosine. Sections were apposed to tritium-scnsitive Hyperfilm (Amersham) and exposed at room temperature for 14 days. 


\section{RESULTS}

Cloning of $g p A_{2} R \quad D N A$. PCR using guinea pig brain cDNA as templates amplified several bands with sizes compatible with the G-protein-coupled receptor fragments flanked by the corresponding primers. Sequence analysis of these PCR fragments revealed different sequences with various homologies (from $62 \%-88 \%$ ) to cDNA sequences encoding dog and rat $A_{1}$ and $A_{2}$ adenosine receptors. The mixture of these PCR products was directly labeled with ${ }^{32} \mathrm{P}$ and used as probe to screen guinea pig brain pME18S cDNA library by low-stringency hybridization to get full-length clones. Twentyone positive clones were obtained in $3 \times 10^{5}$ colonies screened. One of these full-length clones, $\mathrm{gpA}_{2} \mathrm{R}$, showed highest homology to $\mathrm{A}_{2}$ adenosine receptors.

Sequence Analysis of $g p A_{2} R$. Clone $\mathrm{gpA}_{2} \mathrm{R}$ contained an insert of 2,085 base pairs (bp) followed by a poly(A) tail. A long open reading frame was found after an ATG (Methionine) at position 16-18. The sequences around this ATG met the Kozak consensus sequence criteria for a translation initiation site (14). This open reading frame encodes a protein with 409 amino acids (including the first methionine) (Fig. 1) and a calculated molecular mass of 44,831 Daltons.

Genebank search showed that the deduced amino acid sequence of $\mathrm{gpA}_{2} \mathrm{R}$ is highly homologous to the previously cloned $\mathrm{A}_{2}$ adenosine receptors from other species: $88 \%$ identity with $\operatorname{dog} A_{2 a}$ receptor, $87 \%$ with human $\mathrm{A}_{2 \mathrm{a}}, 61 \%$ identity with rat $\mathrm{A}_{2 \mathrm{~b}}$, and $58 \%$ with human $\mathrm{A}_{2 \mathrm{~b}}$. The protein sequence of $\mathrm{gpA}_{2} \mathrm{R}$ also shares $51 \%$ identity with dog, rat and bovine $A_{1}$ adenosine receptors. Its similarities with other members of the Gprotein coupled receptor superfamily are lower but significant (for example, in transmembrane regions, 34\% identity with rat $5-\mathrm{HT}_{1 \mathrm{~A}}$ receptor, $30 \%$ with human and rat $\alpha_{1}$-adrenergic receptor, $29 \%$ with human histamine $\mathrm{H}_{2}$ receptor, and $29 \%$ with human $\mathrm{D}_{2}$ dopamine receptor).

Computer-aided hydrophobicity analysis (method of Kyte \& Doolittle) (15) of $\mathrm{gpA}_{2} \mathrm{R}$ revealed that it contains seven hydrophobic segments, each consisting of about 23-27 amino acid residues, long enough to form a $\alpha$-helix to span the cell membrane. These hydrophobic regions possess the highest similarities to many other Gprotein-coupled receptors. Several features of the aminoacid sequence of $\mathrm{gpA}_{2} \mathrm{R}$ are noteworthy, and are also conserved in all other cloned $A_{2}$ receptors: The N-terminal hydrophilic region before the TM I is very short (4 residues), and there is no potential $\mathrm{N}$-glycosylation site on this $\mathrm{N}$-terminal extracellular end; two potential
$\mathrm{N}$-glycosylation sites can be found in the second extracellular loop; there are 18 serine and threonine residues after TM VII, which may participate in the mechanism of receptor phosphorylation. The deduced protein sequence of $\mathrm{gpA}_{2} \mathrm{R}$ does not have a signal sequence on its N-terminus.

Receptor Binding Assay on Transfected COS-7 Cells. Simian COS-7 cells, which endogenously expressed neither $\mathrm{gpA}_{1} \mathrm{R}$ or $\mathrm{gpA}_{2} \mathrm{R}$ positively-hybridizing $\mathrm{mRNAs}$ nor detectable $\left[{ }^{3} \mathrm{H}\right] \mathrm{CPX}$ or $\left[{ }^{3} \mathrm{H}\right] \mathrm{CGS} 21680$ binding sites, were transfected with plasmid $\mathrm{gpA}_{2} \mathrm{R}$. Binding assays (both saturation and competition studies) were performed on whole cells.

Cells transfected with plasmid $\mathrm{gpA}_{2} \mathrm{R}$ expressed saturable, high affinity binding sites for selective $\mathrm{A}_{2}$ agonist $\left[{ }^{3} \mathrm{H}\right]$ CGS $21680\left(\mathrm{~K}_{\mathrm{d}}=5.7 \mathrm{nM}\right)$, specific binding was about $75-80 \%$ of total binding (Fig. $2 \mathrm{~A}$ ). $\mathrm{A}_{1}$-selective agonists $\left[{ }^{3} \mathrm{H}\right] \mathrm{CCPA},\left[{ }^{3} \mathrm{H}\right] \mathrm{CHA}$ and antagonist $\left[{ }^{3} \mathrm{H}\right] \mathrm{CPX}$ showed very little binding to gp $\mathrm{A}_{2} \mathrm{R}$ (data not shown). Binding assays performed with cell membrane preparations gave similar results.

In competition studies, the selective $\mathrm{A}_{2}$ agonist CGS21680 competed well with [ $\left.{ }^{3} \mathrm{H}\right] \mathrm{CGS} 21680$ binding on $\mathrm{gpA}_{2} \mathrm{R}$ transfected COS-7 cells, the non-selective adenosine agonist NECA and antagonist XAC were also good competitors, while the relatively selective $A_{2}$ agonist MECA and the $\mathrm{A}_{2}$ antagonists DMPX and DPMX exhibited moderate competitions. In contrast, the selective $\mathrm{A}_{1}$ agonists CCPA, $\mathrm{CHA}$ and the $\mathrm{A}_{1}$ antagonist $\mathrm{CPX}$ competed very poorly. ATP did not compete $\left[{ }^{3} \mathrm{H}\right] \mathrm{CGS} 21680$ binding. The rank order of these ligands to compete with [ $\left.{ }^{3} \mathrm{H}\right] \mathrm{CGS} 21680$ binding on $\mathrm{gp}_{2} \mathrm{R}$ transfected cells was as follows: $\operatorname{CGS} 21680>>\mathrm{XAC}=$ NECA $>>$ adenosine $=$ MECA $=$ DMPX $=$ DPMX $>$ R-PIA $=\mathrm{CPA}>\mathrm{CHA}>\mathrm{CPX}>>$ ATP (Fig. 2B).

The Effects of $A_{2}$ Ligands on GTPase Activity and $c A M P$ Level in $g p A_{2} R$ Transfected COS Cells. The $\mathrm{A}_{2}$ agonist CGS 21680 stimulated GTPase activity up to $37 \%$ above control level and increased cAMP level by two-fold in $\mathrm{gpA}_{2} \mathrm{R}$ transfected cells. These effects could be partially blocked by the $A_{2}$ antagonist DMPX. $A_{1}$ agonists had very little effect on GTPase activity and cAMP levels in the same transfectants (Table I).

Northern Hybridization in Different Guinea Pig Tissues. Northern blot analysis of total RNAs from 8 tissues of the guinea pig probed with $\mathrm{gpA}_{2} \mathrm{R}$ RNA probe showed a single hybridized transcript of approximately $3 \mathrm{~kb}$ in brain, heart, spleen and kidney (Fig. 3).

In Situ Hybridization. Within the brain, $\mathrm{gpA}_{2} \mathrm{R}$ mRNA appeared to be exclusively localized in the caudate/putamen (Fig. 4). After a two-week exposure time, 


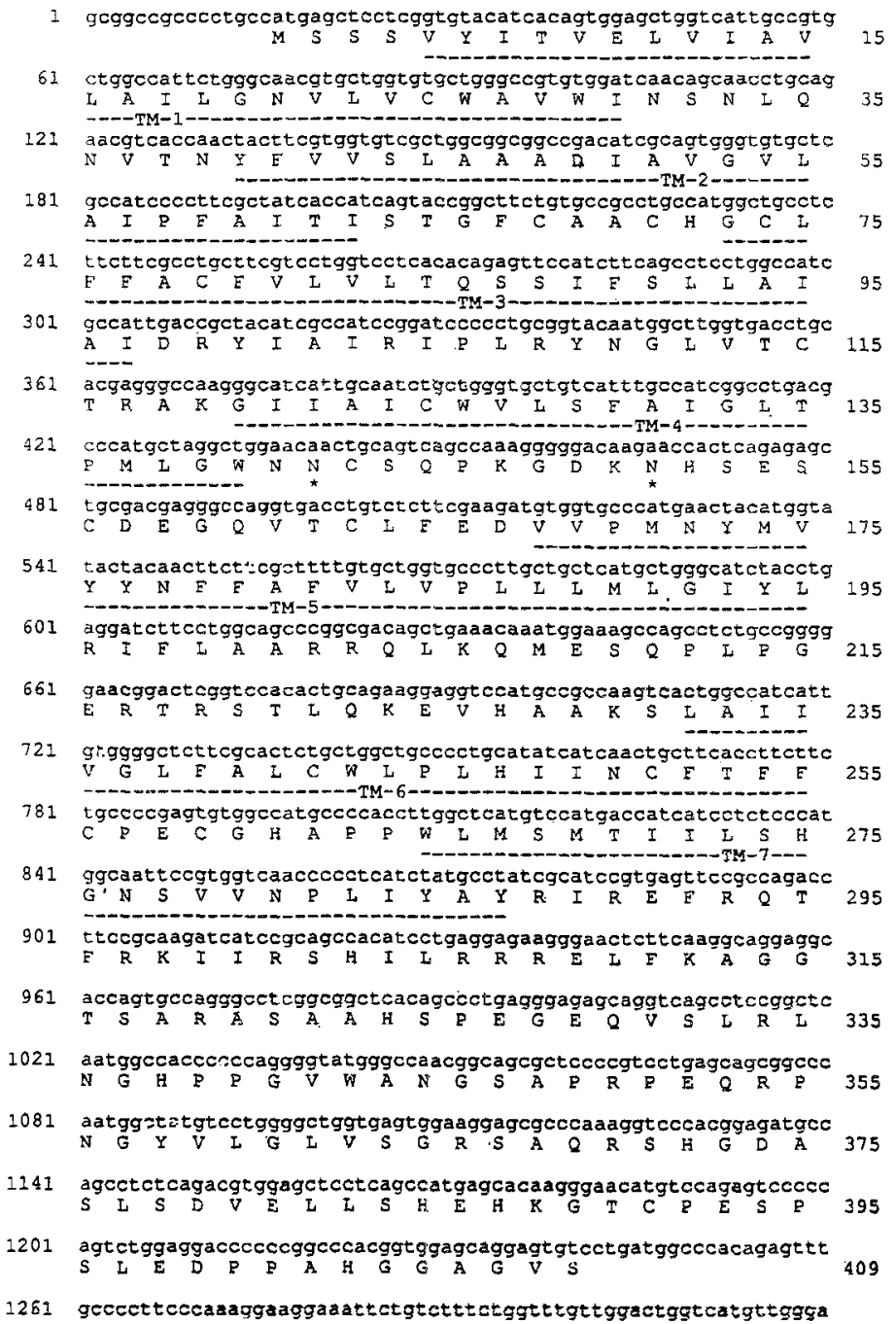

Fig. 1. Nucleotide and deduced amino acid sequence of $\mathrm{gpA}_{2} \mathrm{R}$.

Nucleotides are numbered on the left of the rows and amino acids on the right. Possible N-glycosylation sites $\left({ }^{*}\right)$ are marked and polyadenylation signal sequence underlined. Putative hydrophobic transmembrane domains TM-1 through TM-7 are underlined with broken lines. The sequence has been deposited to GenBank data base (accession no. U04201).

the level of $\mathrm{gpA}_{2} \mathrm{R}$ mRNA expression in the caudate was 8 -fold greater (as measured by mean O.D.) than that in adjacent cortical areas. The complementary distribution of $\mathrm{A}_{2}$ receptor binding sites in this region indicates that
$\mathrm{A}_{2}$ receptors are intrinsically localized within the striatum. $A_{2}$ mRNA was undetectable within the cerebral cortex, hippocampus, substantia nigra and cerebellum (Fig. 4). 

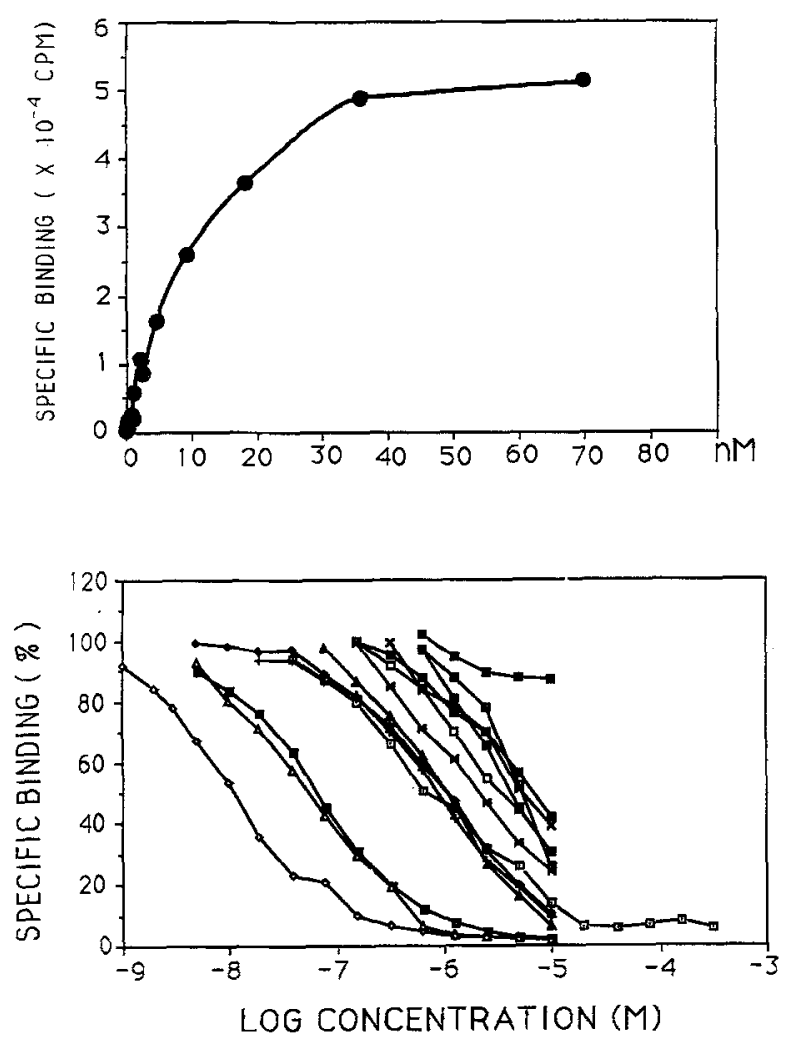

Fig. 2. Radio-ligand receptor binding assay on gpA2R transfected COS-7 cells. (A) Saturation curve of [ $\left.{ }^{3} \mathrm{H}\right]$ CGS21680 specific binding. Twenty micromoler of unlabeled CGS21680 are used as total dispacement. (B) Competition of [ $\left.{ }^{3} \mathrm{H}\right]$ CGS21680 specific binding by CGS21680 $(\diamond)$, XAC $(\triangle)$, NECA $(\square), \operatorname{MECA}(+)$, adenosine $(\mathbf{A}), \operatorname{IBMX}(\varpi)$,

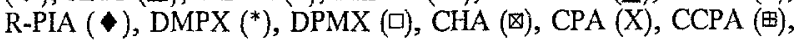
CPX (घ), ATP (๘).

\section{DISCUSSION}

$\mathrm{A}_{2}$ adenosine receptors, which positively activate adenylyl cyclase through Gs-protein, have been proposed to have $A_{2 a}$ and $A_{2 b}$ subtypes (1). $A_{2 a}$ receptors have high-affinity binding for the specific $A_{2}$ agonist
CGS21680 and the endogenous ligand adenosine, while $A_{2 b}$ bind CGS21680 and adenosine with considerably lower affinity $(25,36)$. The anatomical distributions of the two subtypes of $\mathrm{A}_{2}$ receptors in the CNS are also very different: $A_{2 a}$ receptors are located within the striatum, while $A_{2 b}$ receptors are not found in the brain proper but only found in the hypophyseal pars tuberalis of the pituitary (34).

The cloned guinea pig brain cDNA, $\mathrm{gpA}_{2} \mathrm{R}$, exhibits highest homologies to the $\operatorname{dog}(88 \%)$ and human (87\%) $A_{2 a}$ adenosine receptors; its degrees of homology are lower to the $A_{2 b}$ and $A_{1}$ adenosine receptors (approximately $60 \%$ to $A_{2 b}$ and $50 \%$ to $A_{1}$ ). The expressed $\mathrm{gpA}_{2} \mathrm{R}$ has high affinity binding $(5.7 \mathrm{nM})$ for the $\mathrm{A}_{2}$ selective agonist CGS21680. Stimulation of cells expressing gp $\mathrm{A}_{2} \mathrm{R}$ by CGS21680 increases the cellular cAMP level. The $\mathrm{gpA}_{2} \mathrm{R}$ mRNA is located in the striatum of the brain. Therefore, this cloned $\mathrm{gpA}_{2} \mathrm{R}$ is likely to encode an $\mathrm{A}_{2 \mathrm{a}}$ subtype adenosine receptor. As of this writing, only the $A_{2 a}$ receptors from dog and human have been cloned. Thus the guinea pig $A_{2 a}$ receptor represents the first $A_{2 a}$ subtype to be cloned from a rodent species.

All the existing adenosine agonists and antagonists were developed, tested and defined with mammalian brain membrane preparations or whole animals prior to the molecular cloning of the adenosine receptors. Obviously, these systems contain a mixture of adenosine receptors $\left(A_{1}, A_{2}\right.$ and other subtypes). The expression of a pure population of a single receptor subtype from cloned cDNA has proved to be an invaluable system for evaluating pharmacological ligands. With transiently expressed guinea pig $A_{1}$ (data not shown) and $A_{2 a}$ adenosine receptor, we have tested a dozen adenosine ligands and obtained their ligand selectivity profiles (LSP) and their receptor binding site signatures (BSS) (10). Clearly, CGS21680 displayed highly selective, high-affinity binding to $\mathrm{gpA}_{2} \mathrm{R}$. NECA and MECA bound $\mathrm{gpA}_{2} \mathrm{R}$ with moderate affinities and poor selectivities. Antagonists DMPX and DPMX showed some selectivity towards $A_{2}$

Table I. GTPase and cAMP Assay on gpA 2 R Transfected COS-7 Cells

\begin{tabular}{ccccccc}
\hline & Control & 10 & $\begin{array}{c}\text { CGS21680 }(\mu \mathrm{M}) \\
1\end{array}$ & 0.1 & $\begin{array}{c}\text { CGS21680 (10 } \mu \mathrm{M}) \\
+ \text { DPMX }(10 \mu \mathrm{M})\end{array}$ & CPA $(10 \mu \mathrm{M})$ \\
\hline $\begin{array}{c}\text { GTPase activity } \\
(\%)\end{array}$ & $100 \pm 5$ & $137 \pm 6^{*}$ & $128 \pm 5^{*}$ & $109 \pm 5$ & $113 \pm 7$ & $107 \pm 4$ \\
$\begin{array}{c}\text { Cyclic AMP level } \\
(\%)\end{array}$ & $100 \pm 6$ & $194 \pm 7^{* *}$ & $172 \pm 4^{* *}$ & $138 \pm 3^{*}$ & $144 \pm 5^{*}$ & $128 \pm 3^{*}$ \\
\hline
\end{tabular}

Data are presented as Mean \pm SE of triplicates. In control group, GTPase activity and cAMP level of transfected COS-7 cells were measured without the application of ligands. ${ }^{*} \mathrm{P}<0.05,{ }^{* *} \mathrm{P}<0.01$ as compared with control (Student $t$ test). 


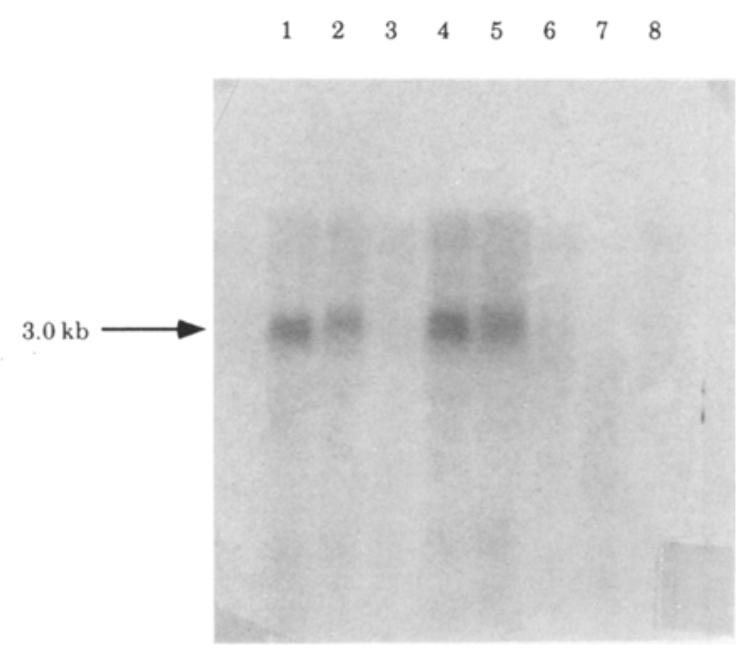

Fig. 3. Northern hybridization of RNAs from different guinea pig tissues. Guinea pig total RNAs from (1) brain, (2) heart, (3) lung, (4) spleen, (5) kidney, (6) liver, (7) stomach, and (8) intestine were probed with $\mathrm{gpA}_{2} \mathrm{R}$ riboprobe $\left(9.0 \times 10^{6} \mathrm{cpm} / 20 \mathrm{ml}\right)$ and exposed for 6 days at $-80^{\circ} \mathrm{C}$ with two intensifying screens. The molecular weight was based on a RNA ladder (BRL) and a Ribosomal RNA marker (Pharmacia).

but their affinities were also moderate. The endogenous ligand adenosine bound $\mathrm{gpA}_{2} \mathrm{R}$ as well as $\mathrm{A}_{1}$ adenosine receptor with an affinity of about $20 \mathrm{nM}$.

In situ hybridization studies demonstrated that the $A_{2 a}$ receptor mRNA is exclusively expressed in the caudate. The complementary distribution of adenosine $A_{2 a}$ receptor binding in this region indicates that locally synthesised $A_{2 a}$ receptors are present on striatal neurons. Most striatal neurons utilize GABA as a neurotransmitter and can be divided into two sub-populations on the basis of their efferent projections; striatopallidal neurons and striatonigral neurons (9). Striatopallidal neurons have been shown to express enkephalin while striatonigral cells coexpress dynorphin and substance $\mathrm{P}(9,11) . \mathrm{A}_{2 \mathrm{a}}$ receptor mRNA has been shown to be co-localized with enkephalin in striatal cells but not with substance $P(31)$. Thus, striatal $A_{2 \mathrm{a}}$ receptors are likely to be more important in relation to striatopallidal circuitry as opposed to striatonigral. Such differentiation has important implications for the functionality of striatal $A_{2 a}$ receptors and their involvement in the control of locomotor activity. Indeed, stimulation of these sites may underlie the locomotor depressing effects of adenosine analogs (7). In addition, the $\mathrm{A}_{2 \mathrm{a}}$ receptor appears to be co-localized spe-
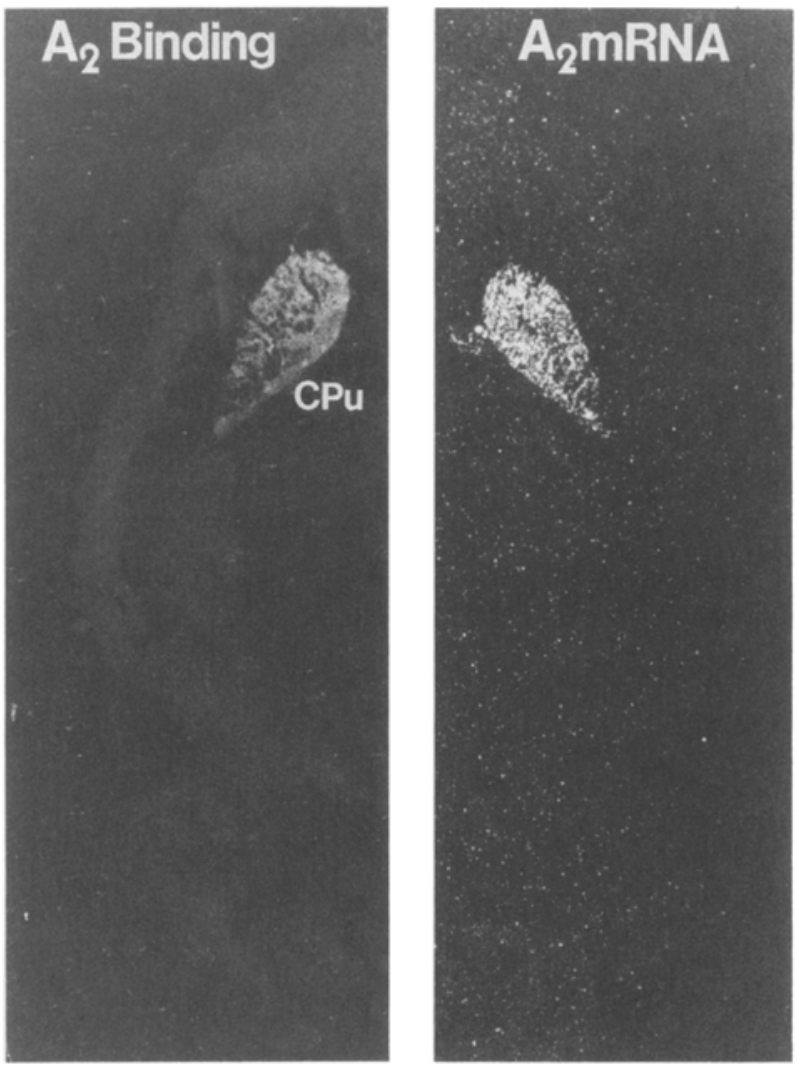

Fig. 4. Conparative autoradiographic localization of $\mathrm{A}_{2}$ receptor sites (left hemisphere) and gp $A_{2} R$ mRNA (right hemisphere) in horizontal sections of guinea pig brain. $\mathrm{CPu}$, caudate/putamen.

cifically with dopamine $D_{2}$ receptors in the caudate $(32,33)$. Further understanding of the interactions between dopaminergic nigrostriatal inputs and the actions of striatal adenosine are likely to be crucial to our understanding of basal ganglia physiology and pathology.

In addition to its role as a neurotransmitter in the $\mathrm{CNS}$, adenosine acts in an autocrine or paracrine fashion to regulate mammalian cardiovascular, renal, and immune systems (40). The activation of adenosine receptors in the heart increases coronary blood flow via vasodilation of coronary arteries, decreases heart rate and contractility. The increase in coronary blood flow is thought to be mediated by $\mathrm{A}_{2}$ adenosine receptors (39). In the kidney, adenosine can decrease glomerular filtration rate, stimulate renin release, and increase sodium excretion. The latter function is thought to be mediated by $A_{2}$ adenosine receptors $(8,13)$. Evidence also indicates that adenosine is involved in the immune system. While adenosine inhibits the production and stimulation 
of lymphocytes (29), the activation of $A_{2}$ receptors protects endothelial cells from injury by inhibiting neutrophil adherence (3).

By Northern blot analysis, we have determined that $\mathrm{gpA}_{2} \mathrm{R}$ mRNA is found in the brain, kidney, and spleen. Given the reported functions of adenosine, the peripheral distribution of $\mathrm{gpA}_{2} \mathrm{R} \mathrm{mRNA}$ is consistent with the idea that $\mathrm{A}_{2}$ type adenosine receptors may mediate some of the effects of adenosine in the cardiovascular, renal, and immune systems, as well as the CNS.

\section{ACKNOWLEDGMENT}

We thank DNAX Research Institute (Palo Alto, California) for supporting Dr. Guo-xi Xie in constructing the cDNA libraries. DNAX Research Institute is supported by Schering-Plough Corporation. We also thank Dr. Kazuo Maruyama for providing the pME18S vector. This project is supported by grants from the Peptide Research Center at University of Michigan (NIDDKD AM34933), from NIDA (DA02265), from NIMH (MH42251) and the Lucille P. Markey Charitable Trust (88-46).

\section{REFERENCES}

1. Bruns, R. F., Lu, G. H., and Pugsley, T, A. 1986. Characterization of the $A 2$ adenosine receptor labeled by $\left[{ }^{3} \mathrm{H}\right] \mathrm{NECA}$ in rat striatal membranes, Molecular Pharmacology, 29:331-346.

2. Cassel, D., and Selinger, Z. 1976. Catecholamine-stimulated GTPase activity in turkey erythrocyte membranes. Biochimmica et Biophysica Acta 452:538-551.

3. Cronstein, B. N., Levin, R. I., Philips, M., Hirschhorn, R., Abramson, S. B. 1992. Neutrophil adherence to endothelium is enhanced via adenosine $A 1$ receptors and inhibited via $A 2$ receptors, J. Immunol., 148:2201-6.

4. Fastbom, J., Pazos, A., and Palacios, J. M. 1987. The distribution of adenosine A1 receptors and $5^{\prime}$ nucleotidase in the brain of some commonly used experimental animals. Neuroscience 22:813-826.

5. Feinberg, A. P., and Vogelstein, B. 1983. A technique for radiolabeling DNA restriction endonuclease fragments to high specific activity. Anal, Biochem. 132:6-13.

6. Ferkany, J. W., Valentiner, H. L., Stone, G. A., and Williams, M. 1986. Adenosine A1 receptors in mammalian brain: Species differences in their interactions with agonists and antagonists. Drug Dev. Res. 9:85-93.

7. Ferre S., Herrera-Marschitz M., Grabowska-Anden M., Ungerstedt U., Casas M., and Anden N-E. 1991. Postsynaptic dopamine/adenosineineraction I. Adenosine analogues inhibit dopamine $\mathrm{D}_{2}$-mediated behaviour in short-term reserpinized mice. Eur. J. Pharmacol. 192:25-30.

8. Freissmuth, M., Nanoff, C., Tuisl, E., and Schuetz, W. 1987. Stimulation of adenylate cyclase activity via $\mathrm{A}_{2}$-adenosine receptors in isolated tubules of the rabbit renal cortex, Eur. J. Pharmacol. 138:137-40.

9. Gerfen, C. R., and Young W. S. III. 1988. Distribution of striatonigral and striatopallidal peptidergic neurons in both patch and matrix compartments: an in situ hybridization histochemistry and fluorescent retrograde tracing study. Brain Res. 460:161-167.

10. Goldstein, A., and Naidu, A. 1989. Multiple opioid receptors: Ligand selectivity profiles and binding site signatures. Mol. Pharmacol. 36:265-272.
11. Graybiel A. M. 1990. Neurotransmitters and neuromodulators in the basal ganglia. Trends Neurosci. 13:244-254.

12. Gubler, U., and Hoffman, B. J. 1983. A simple and very efficient method for generating cDNA library. Gene 25 (2-3):263-269.

13. Itoh, S., Carretero, O. A., and Murray, R. D. 1985. Possible role of adenosine in the macula densa mechanism of renin release in rabbits. J. Clin. Invest. 76:1412-17.

14. Kozak, M. 1984. Compilation and analysis of sequences upstream from the translational start site in eukaryotic mRNAs. Nucleic Acids Res. 12:857-872.

15. Kyte, J., and Doolittle, R. F. 1982. A simple method for displaying the hydropathic character of a protein. J. Mol. Biol. 157:105-132.

16. Libert, F., Parmentier, M., Lefort, A., Dinsart, C., Van Sande, J., Maenhaut, C., Simons, M.-J., Dumont, J. E., and Vassart, G. 1989. Selective amplification and cloning of four new members of the G protein-coupled receptor family. Science 244:569-572.

17. Libert, F., Schiffman, S. N., Lefort, A., Parmentier, M., Gerard, C., Dumont, J. E., Vanderhaegen, J.-J., and Vassart, G. 1991. The orphan receptor cDNA RDC7 encodes an $\mathrm{A1}$ adenosine receptor. The EMBO Journal 10:1677-1682.

18. Maenhaut, C., Van Sande, J., Libert, F., Abramowicz, M., Parmentier, M., Vanderhaegen, J. J., Dumont, J. E., Vassart, G., and Schiffmann, S. 1990. RDC8 codes for an adenosine A2 receptor with physiological constitutive activity. Biochem. Biophys. Res. Comm. 173:1169-1178.

19. Mahan, L. C., McVittie, L. D., Smyk-Randall, E. M., Nakata, H., Monsma, F. J., Jr., Gerfen, C. R., and Sibley, D. R. 1991. Cloning and expression of an $\mathrm{Al}$ adenosine receptor from rat brain. Molecular Pharmacology 40:1-7.

20. Maruyama, K., and Takebe, Y. 1990. New trend of cDNA cloning. Mcd. Immunol. (Tokyo) 20:27-32.

21. Munson, P. J. and Rodbard, D. 1980. Ligand: a versatile computerized approach for characterization of ligand-binding systems. Anal. Biochem. 107:220-239.

22. Neumann, E., Schacfer-Ridder, M., Wang, Y., and Hofschneider, P. H. 1982. Gene transfer into mouse lyoma cells by electroporation in high electric fields. EMBO J. 1:841-845.

23. Okayama, H., and Berg, P. 1982. High-efficiency cloning of fulllength cDNA. Mol. Cell. Bio. 2:161-170.

24. Olah, M. E., and Stiles, G. L. 1992. Adenosine receptors. Annu. Rev. Physiol. 54:211-225.

25. Pierce, K. D., Furlong, T. J., Selbie, L. A., and Shine, J. 1992. Molecular cloning and expression of an adenosine $A 2 b$ receptor from human brain, Biochem. Biophys. Res. Commun. 187:8693.

26. Reppert, S. M., Weaver, D. R., Stehle, J. H., and Rivkees, S. A. 1991. Moleculat cloning and characterization of a rat A1adenosine receptor that is widely expressed in brain and spinal cord. Molecular Endocrinology 5:1037-1048.

27. Saiki, R. K., Gelfand, D. H., Stoffel, S., Scharf, S. J., Higuchi, R., Horn, G. T., Mullis, K. B., and Erlich, H. A. 1988. Primerdirected enzymatic amplification of DNA with a thermostable DNA polymerase. Science 239:487-491.

28. Sambrook, J., Fritsch, E. F., and Maniatis, T. 1989. in Molecular Cloning, 2nd Edition. (Cold Spring Harbor Laboratory Press).

29. Samet, M. K. 1985. Inhibition of antibody production by 2-chloroadenosine, Life Sci. 37:225-33.

30. Sanger, F., Nicklen, S., and Coulson, A. R. 1977. DNA sequencing with chain-terminating inhibitors. Proc. Natl. Acad. Sci. USA 74:5463-5467.

31. Schiffmann, S. N., Jacobs, O. P., Vanderhaeghen, J.-J. 1991. Striatal restricted adenosine A2 receptor (RDC8) is expressed by enkephalin but not by substance $P$ neurons: an in situ hybridization histochemistry study. J. Neurochem. 57:1062-1067.

32. Schiffmann, S. N., Libert, F., Vassart, G., and Vanderhaeghen, J.-J. 1991. Distribution of adenosine A2 receptor mRNA in the human brain. Neurosci. Lett. 130:177-181.

33. Schiffmann, S. N., and Vanderhaeghen, J.-J. 1993. Adenosine 
$A_{2}$ receptors regulate the gene expression of striatopallidal and striatonigral neurons. J. Neurosci. 13:1080-1087.

34. Stehle, J. H., Rivkees, S. A., Lee, J. J., Weaver, D. R., Deeds, J. D., and Reppert, S. M. 1992. Molecular cloning and expression of the cDNA for a novel A2-adenosine receptor subtype, Molecular Endocrinology 6:384-393.

35. Stiles, G. L. 1992. Adenosine receptors. J. Bio. Chem. 267:64516454.

36. Stone, G. A., Jarvis, M. F., Sills, M. A., Weeks, B., Snowhill, E. W., and Williams, M. 1988. Species differences in high-affinity adenosine $\mathrm{A} 2$ binding sites in striatal membranes from mammalian brain. Drug Development Research 15:31-46.

37. Takebe, Y., Seiki, M., Fujisawa, J.-1., Hoy, P., Yokota, K., Arai, K.-I., Yoshida, M., and Arai, N. 1988. SRa promoter: an efficient and versatile mammalian cDNA expression system composed of the simian virus 40 early promoter and the R-U5 segment of human T-cell leukemia virus type I long terminal repeat. Mol. Cell. Biol. 8:466-472.
38. Tucker, A. L., Linden, J., Robeva, A. S., D’Angelo, D. D., and Lynch, K. R. 1992. Cloning and expression of a bovine adenosine A1 receptor cDNA. FEBS Letters 297(1,2):107-111.

39. Uecda, M., Thompson, R. D., Arroyo, L. H., Olsson, R. A. 1991. 2-Alkoxyadenosines: Potent and selective agonists at the coronary artery $\mathrm{A}_{2}$ adenosine receptor. J. Mcd. Chem. 34:134044.

40. Williams, M. 1987. Purine receptors in Mammalian tissues: Pharmacology and functional significance. Ann. Rev. Pharmacol. Toxicol. 27:315-45.

41. Young, W. S., III, Bonner, T. I., Brann, M. B. 1986. Mesencephalic dopamine neurons regulate the expression of neuropeptides mRNA's in rat basal ganglia. Proc, Natl. Acad. Sci. USA 83:9827-9831.

42. Zhou, Q. Y., Li, C., Olah, M. E., Johnson, R. A., Stiles, G. L., and Civelli, O. 1992. Molecular cloning and characterization of an adenosine receptor: the $\mathrm{A} 3$ adenosine receptor. Proc. Natl. Acad. Sci. USA 89:7432-7436. 